\title{
Die ontwikkeling vanaf 'n simplistiese na 'n gevorderde agrariese ekonomie in die leefwêreld van die Bybel ${ }^{1}$
}

\author{
G J Volschenk
}

Navorsingsassosiaat: Departement Nuwe-Testamentiese Wetenskap

Universiteit van Pretoria

\begin{abstract}
The development of the agrarian society of the Bible from a simplistic to an advanced agrarian society

The aim of this article, is to study the development of the ancient economy from a simplistic agrarian society to an advanced agrarian society. The Hasmonian Empire formed the bridge from a simplistic to an advanced agrarian society. The Roman Empire was the end product of the evolution process and an example of the advanced agrarian society.
\end{abstract}

\section{INLEIDING}

Die onderhawige artikel bou voort op 'n vorige wat gefokus het op die ontwikkeling van 'n horti-kulturele na 'n simplistiese agrariese ekonomie in die leefwêreld van die Bybel (Volschenk 2002). Hierdie artikel het ten doel om die opkoms van die Hasmoniese Ryk te beskryf as ' $n$ oorgang vanaf die simplistiese agrariese samelewing na die gevorderde agrariese samelewing waarvan die Romeinse Ryk 'n voorbeeld is. Polities het die Jode onder die Seleukiede 'n tyd van stabiliteit, vryheid en herstel beleef. 'n Ekonomiese resessie is veroorsaak deur droogte, misoeste en voortdurende oorloë ${ }^{2}$. Die opkoms van

\footnotetext{
${ }^{1}$ Dr Gert J Volschenk (MDiv, DD) is as navorsingsassosiaat betrokke by prof dr Andries G van Aarde se navorsingsprojek "Bybelse Teologie en Hermeneutiek", Departement Nuwe Testamentiese-Wetenskap, Fakulteit Teologie, Universiteit van Pretoria.

2 Josefus se werke, War, Life en Jewish Antiquities, beskryf die spanning en oorloë tussen die Jode en die Romeine (kyk Freyne 2000:27-44).
} 
die Romeinse mag het aanleiding gegee tot die eksploitasie van die Jode op alle terreine, naamlik polities, ekonomies en godsdienstig. Die opkoms van die Hasmoniese Ryk het verdeeldheid onder die Jode gebring, naamlik enersyds die meer ge-Helleniseerde opperklasse en andersyds die landvolk en kleinboere. Die konflik en verdeeldheid het gelei tot die kleinboeropstande.

Die gevorderde agrariese samelewing is die produk van 'n lang evolusieproses. In Afdeling 3 sal Lenski se model van die gevorderde agrariese samelewing beskryf word. Die ontdekking van yster en verharding van staal kan beskou word as die begin van die gevorderde agrariese samelewing. 'n Verskeidenheid van ambagte het ontwikkel en sommige families en dorpies het in 'n spesifieke ambag gespesialiseer. Die ekonomie van die gevorderde agrariese samelewing is ' $\mathrm{n}$ bestaansekonomie. Dit kan verdeel word in 'n landelike landbou ekonomie en 'n stedelike vervaardigings- en handelsektor. Die elite in die stad het die ekonomie beheer en het die landvolk en kleinboere op die platteland geëksploiteer deur middel van belastings en heffings. Die familie was die middelpunt in die gevorderde agrariese samelewing.

In Afdeling 4 word die Romeinse Ryk ondersoek as voorbeeld van die gevorderde agrariese samelewing. Die ondersoek toon dat die volgende tendense kenmerkend is van die Romeinse Ryk.

- Stryd tussen die stad en platteland: die elite in die stad eksploiteer die kleinboere deur middel van heffings en belastings (vgl Josefus, Life 44; War 2.457; Freyne 2000:45-54);

- Die Romeine se grondbesit persepsie verskil van die kleinboere wat grond as gawe van God aan die familie en dus erfgoed beskou wat nie verhandelbaar is nie.

- Die familie verkeer onder geweldige druk as gevolg van ekonomiese differensiasie (kyk Josefus, Life 55. 100. 171; Freyne 2000:57);

- Sosiale stratifikasie neem toe as gevolg van die stryd tussen die elite en kleinboere. 


\section{PALESTINA ONDER DIE SELEUKIEDE}

\subsection{Politieke oorname}

Antiochus III van Sirië het in 201-200 die hele suidelike Sirië, Palestina en die kusgebiede verower en Scopas en die Egiptiese leër verslaan te Paneas in die noordelike deel van Palestina. Na die oorwinning van Antiochus III het die pro-Seleukidiese hoëpriester Simon II die mag in Jerusalem oorgeneem. Antiochus het 'n dekreet uitgevaardig waardeur die Jode vergoed word vir hulle hulp aan die Seleukiede teen die Ptolemeërs. Die dekreet het bepaal dat Joodse gevangenes vrygelaat word en die skade aan Jerusalem herstel word, insluitende die invoer van gratis hout vir die herstel van die tempel. Antiochus het hulle vir drie jaar vrygestel van belasting sodat hulle hulle weer in Jerusalem kon vestig. Antiochus het hulle toegelaat om te leef volgens hulle eie wette en die hoëpriester en die raad het as regerende liggaam in Judea opgetree (Kee 1997:292; Louw 1983:99, 100).

\subsection{Ekonomiese resessie}

Die ekonomiese vooruitgang van die Ptolemese periode is opgevolg deur ekonomiese resessie onder die Seleukidiese oorheersing. Die oorsake van die ekonomiese agteruitgang het gewissel van droogte, misoeste en veral die voortdurende oorloë. Hengel (1973:47) skryf die ekonomiese resessie van die tweede eeu in Palestina onder die Seleukiede toe aan 'n verskeidenheid van faktore wat toekomstige ontwikkelings belemmer het. Die belangrikste oorsaak is die uitgerekte oorloë, onder andere die verowering van Palestina deur Antiochus III; die groot skade van die Seleukidiese oorlog teen Rome het hoë belastings tot gevolg gehad en laastens die Makkabese brvrydings$\operatorname{oorlog}^{3}$ gevolg deur die Hasmonese veroweringsoorlog. Baie gemeenskappe het tot niet gegaan deels as gevolg van vernietiging en deels deur verarming en die wegtrek van die inwoners.

${ }^{3}$ Josefus se werke is 'n omvattende beskrywing van die polities-ekonomiese toestande van die eerste-eeuse Judea. Josefus se War en Jewish Antiquities gee 'n oorsig oor die oorlog tussen die Jode en die Romeine (kyk McLaren 1998). 


\subsection{Opkomende Romeinse mag, wedywering en opstand}

Antiochus III het ten doel gehad om 'n groot Griekse ryk tot stand te bring. Dit is bereik deur politieke en kulturele hegemonie van die stad (polis). Die Seleukiede-huis het groeiende probleme ervaar in die lig van die opkomende Romeinse mag. Die opkomende Romeinse mag het swaarder geweeg in die beleidsbepalings van die Seleukiede, as die plaaslike realiteite of administratiewe organisering. Die Seleukiede se beleid was dus: verenig en heers. Antiochus III is in $190 \mathrm{vC}$ deur die Romeine verslaan in die stryd van Magnesia in die westelike Klein-Asië. Hy is geheel en al uit Griekeland en Klein-Asië verban.

Antiochus IV het 'n groot krisis vir die Joodse volk veroorsaak. Antiochus IV het begin met die verpligting om ander gode naas Jahwe in die Jerusalem tempel te aanbid, veral Zeus, waarvan laasgenoemde die aardse verteenwoordiger is. Antiochus IV het die mense op die platteland gedwing om afgode te aanbid en het Joodse gebruike, soos Sabbatdagheiliging, besnydenis en die onderhouding van die Tora, met die doodstraf strafbaar gemaak (Kee 1997:306; Louw 1983:102). Dit was veral die regerende opperklasse wat gekonformeer het en deel was van die Helleniseringsproses. Die ongeletterde massa inwoners het die Joodse tradisies gehandhaaf. Om sake vir die Jode te vererger het Antiochus IV die hoërpriesterskap in Jerusalem aangebied vir die hoogste bieder. Die oorsaak van bogenoemde optrede was Antiochus se geldnood. Die lang jare van oorlog teen die Ptolemeërs en die geweldige kostes om die uitgestrekte ryk te administreer, het sy beurs uitgeput. Die eerste stap was aansienlike belastingverhogings en vir die Jode die ontstemmende praktyk van om die hoëpriesteramp te verkoop aan die hoogste bieder. Jason, die broer van Onias III het Antiochus oorreed om hom aan te stel as hoëpriester, en in ruil daarvoor sal meer belasting ingevorder en sleutel Griekse instellings gevestig word, soos 'n gimnasium. 'n Toegewyde groep Jode het probeer om Jerusalem in 'n Griekse stad te verander (Kee 1997:307; Louw 1983:102).

Die voortslepende wedywering om die hoëpriesteramp het Antiochus se mag begin bedreig en laasgenoemde het in woede teen die Jode opgetree. Die tempel is ontheilig deur ' $n$ altaar vir Zeus in die tempel in Jerusalem op te rig en hulle gebruike te verbied (168 vC). Die vernietiging van die gewoontereg - die Tora - het die Makkabese opstand en daarmee saam die Joodse kleinboeropstand veroorsaak. Saam met die sterk 
apokaliptiese verwagtings was daar 'n agrariese element by hierdie opstand betrokke (Louw 1983:104, 108-110; Oakman 1986:42; Kee 1997:310-313).

\subsection{Opkoms van die Hasmoniese ryk}

In $166 \mathrm{vC}$ begin die Makkabeër-tydperk tot en met $63 \mathrm{vC}$, 'n volle eeu waarin die Jode politieke onafhanklikheid geniet het. Die Seleukiede het die Joodse weerstand teen afgodery en die Helleniseringsproses heeltemal onderskat. $\mathrm{Na}$ 'n lang stryd en afname van die Seleukidiese ryk het die Jode uiteindelik onafhanklikheid gekry onder die eerste Hasmoniese heersers. In Griekse geskrifte word die tydperk die Makkabeër-tydperk genoem en in Joodse geskrifte die tyd van die Hasmoneërs. Die Hasmoniese familie het aktiewe weerstand teen die Seleukiede begin bied. Hulle het aangedring dat elke Joodse kind besny moes word en hulle het sondaars en wetteloses, dit wil sê, diegene wat saam met die regeerders gewerk het, doodgemaak. Eers het dit gelyk of daar 'n terugkeer was na agrariese monargie soos in die tyd van Dawid en Salomo. Maar met die opkoms van die Fariseërs onder Johannes Hircanus blyk dit duidelik dat nie alle Jode gelukkig was onder die Hasmoniese ryk nie. Die verdeeldheid en interne magstryd het voortgeduur. Kee (1997:317) stel dat tien jaar se konflik geen oplossing gebied het nie. Die Joodse gemeenskap is steeds verdeeld, die Seleukidiese regering en die Joodse amptenare is steeds in beheer en die Hasmonese mag word bedreig deur die Siriese mag. Die Joodse gemeenskap was verder verdeeld oor die uitleef van die Judaïsme en die respons teenoor die Ryk.

Die Hasmonieërs het die model van die Hellenistiese ryk as hulle eie aangeneem. Johannes Hircanus het later nie meer die ondersteuning van die Hasidim geniet nie en aansluiting gesoek by die meer ge-Helleniseerde en wêreldse Saddusese aristokrasie. Die konflik tussen Janneus en die Fariseërs het ook 'n agrariese aspek gehad. Janneus, die Hasmonieër het outonome Joodse grond terugverander in koninklike grond om daardeur sy baie militêre veldtogte te ondersteun. 'n Joodse kleinboer, wat die vrug van die landbougrond geniet het, sonder die groot las van belasting, is al meer vervreem van 'n toenemende ge-Helleniseerde en onderdrukkende monargie (Oakmann 1986:44). Dimitrius II, die Seleukied, het die Jode finaal onthef van alle buitelandse belasting en Simon 
aangestel as hoëpriester. Die amp is later deur die raad van priesters en oudstes bevestig. Daardeur is die Hasmoniese ryk gevestig en hulle het vir honderd jaar regeer.

\title{
3. GEVORDERDE AGRARIESE GEMEENSKAPPE
}

Lenski (1991:188-222) beskryf die gevorderde agrariese gemeenskap in besonderhede, waarvan die Romeinse Ryk 'n voorbeeld is. Lenski (1991) gee 'n beskrywing van die algemene eienskappe en tendense wat eie is aan 'n gevorderde agrariese gemeenskap.

\subsection{Tegnologie}

Die belangrikste ontdekking in die tyd was die smelt van yster. Brons was belangriker vir die regerende klas en is gebruik vir militêre, estetiese en seremoniële geleenthede. Yster is gebruik vir die maak van gereedskap en wapens. In die tyd kan ons begin praat van gevorderde agrariese gemeenskappe. Die militêre en ekonomiese waarde van yster is verhoog nadat die verharding tot staal ontdek is. Staal het die belangrikste bron geword vir die maak van gereedskap en wapens. "By the time of Christ, advanced agrarian societies were firmly established in the Middle east, throughout most of the Mediterranean world, and in much of India and China" (Lenski 1991:189). Die belangrikste innovasies in die gevorderde agrariese gemeenskap tot en met die negentiende eeu nC word deur Lenski (1991:190) soos volg beskryf:

\begin{abstract}
A partial list would include the catapult, the crossbow, gunpowder, horseshoes, a workable harness for horses, stirrups, the wood-turning lathe, the auger, the screw, the wheelbarrow, the rotary fan for ventilation, the clock, the spinning wheel, porcelain, printing, iron casting, the magnet, waterpowered mills, windmills, and in the period just preceding the emergence of the first industrial societies, the workable steam engine, the fly shuttle, the spinning jenny, the spinning machine, and various other power-driven tools.
\end{abstract}

\subsection{Toenemende differensiasie in die ekonomie}

\subsubsection{Verdeling van arbeid}

Die oorgang van simplistiese na gevorderde agrariese gemeenskappe het groter verdeling van arbeid tot gevolg. Groter ekonomiese en beroepsspesialisasie het plaasgevind binne 
die streke en gemeenskappe. Spesialisasie binne die Romeinse Ryk het ook toegeneem, byvoorbeeld Spanje en Egipte het spesifiek net vleis voorsien en die Swartsee-streek het graan voorsien (Lenski 1991:195). Op die platteland het die kleinboere in die af seisoen ambagte beoefen en selfs dorpies het in 'n spesifieke kommoditeit gespesialiseer en handel gedryf. Spesialisasie binne groot stede is deur 'n groot hoeveelheid mense beoefen en het oor ' $n$ wye front plaasgevind. Spesialisasie was nie net beperk tot groot stede nie. Kleiner stede en dorpies het ook spesialiste in verskeie ambagte en beroepe gehad. Stedelike sentra het spesialis ambagte gehad, asook spesialiste in die regering, handel, godsdiens, opvoeding, weermag en huishoudelike dienste. "There were also specialists in illegal occupations (e g, thieves ${ }^{4}$, prostitutes), which were a normal part of urban life in advanced agrarian societies" (Lenski 1991:195).

\subsubsection{Bestaansekonomie}

Die interafhanklikheid tussen politiek en ekonomie in gevorderde agrariese gemeenskappe het beteken dat diegene wat die politiek beheer, ook die ekonomie beheer het. Die ampsdraers in die regering was ook die primêre grondbesitters. Die beheer van grond en diegene wat dit bewerk het, was die belangrikste ekonomiese bron in hierdie gemeenskappe. Die ware rykdom het beteken om in beheer (om baas) te wees. Lenski (1991:195) onderskei tussen 'n mark gerigte ekonomie en bestaansekonomie: "In these societies, the answers to basic economic questions - how resources should be used, what should be produced and in what quantities, and how those products should be distributed - were determined less by the forces of supply and demand (market economy - GV) than by arbitrary decisions of the political elite."

Die ekonomie in 'n gevorderde agrariese gemeenskap bestaan uit twee onderskeidende dele: 'n landelike landbousektor en 'n stedelike vervaardigings- en handels-

\footnotetext{
4 Boewery was 'n algemene tendens in die eerste-eeuse samelewing (vgl Josefus Life: 126-131; Horsley \& Hanson 1985:16-85; Freyne 2000:49). Verskeie redes is aangevoer vir die oorsake van boewery:

- $\quad$ Ekonomiese uitbuiting van die laer klasse deur die aristokrasie.

- Politieke en ekonomiese krisisse wat deur natuurrampe soos droogte aangehelp word.

- Hoë belasting, uitbuiting en armoede laat mense wend tot rowerbendes.

- $\quad$ Politieke aspekte, soos 'n swak sentrale regering, staatsgrepe of vreemde invalle.

- $\quad$ Politieke bewussyn, verwagtings en die politieke omstandighede van die volk speel ook 'n rol.
} 
sektor. Die onderskeie dele was nie van gelyke belangrikheid nie. Die Romeinse staat het twintig keer meer belasting verhaal van die landbou, as van handel en nywerheid. Bogenoemde belastinglas het ooreengestem met die ekonomiese struktuur van die Romeinse Ryk. Die welvaart is primêr uit die landbousektor verhaal, eerder as van handel en nywerheid. Die stede het die luukse artikels voorsien wat die regerende klas verlang het. Die stedelike ekonomie was afhanklik van die landbou-ekonomie om die surplus te voorsien wat die stedelike populasie ondersteun het (Lenski 1991:196).

Lenski (1991:196) beskryf die ekonomie van die tipiese agrariese gemeenskap met die beeld van 'n boom, waarvan die wortels in elke rigting versprei is om voortdurend nuwe voedingsbronne in te trek. Die middelpunt van die ekonomie is die hoofstad wat deur die koning of keiser en die leiers van die regerende klas beheer word. Rondom die hoofstad is die provinsiale of streekshoofstede wat deur koninklike goewerneurs en ander lede van die regerende klas beheer word. Elkeen van hierdie hoofstede is omring deur kleiner stede wat deur laer stande van die regerende klas beheer word. Laastens, word elkeen van hierdie dorpe omring deur 'n klomp landelike gemeenskappe, van waaruit die ekonomiese surplus verkry word.

Die ekonomiese surplus het beweeg vanaf die periferie, die landelike gebiede en kleinboerprodusente, deur die stede na die middelpunt, naamlik die hoofstad (kyk Josefus Life:30; Freyne 2000:54). Die vloei van ekonomiese surplus is veroorsaak deur belasting, huur, rente, tiendes en ander godsdienstige offers aan die regerende klas van die stad, hulle bondgenote en afhanklikes. Met dit wat oorgebly het na die belastings, het die kleinboere na die stede gegaan en gekoop wat nodig was en wat hulle nie self kon vervaardig nie. Die regerende klas het die wet en orde op sodanige wyse gehandhaaf dat die regte van die regerende klas beskerm word en die kleinboere in 'n onderdanige posisie gehou word. Die handhawing van die orde was baie belangrik in ' $\mathrm{n}$ agrariese gemeenskap, omdat 'n goeie oes afhanklik was van maande se voorafarbeid. Versteuring op enige stadium van die landbousiklus kon rampspoedig wees vir die hele gemeenskap.

\subsubsection{Die landelike ekonomie}

In meeste van die gevorderde agrariese gemeenskappe het die regerende klas (wat godsdienstige leiers insluit) die grootste deel van die grond besit. Een tot drie persent van 
die bevolking het tot twee derdes van die grond besit. Hulle het nie net die grond besit nie, maar ook die kleinboere wat dit bewerk het. Slawerny en groot landgoed gaan hand aan hand. Kleinboere wat hulle eie grond besit het, het gesukkel om 'n bestaan te maak. Die faktore wat hulle nadelig beïnvloed het, is misoeste, belasting en rentes wat hulle moes betaal. Die basiese filosofie van die regerende klas was om die kleinboere tot die maksimum te belas (Josefus, Antiquity 5.63; Lenski 1991:197; Freyne 2000:43).

Die benarde ekonomiese situasie van die kleinboere het baie druk op hulle families geplaas. Die families is van mekaar geskei om die behoeftes van hulle eienaars te pas. Die kleinboer kon moeilik sy vrou en dogters beskerm teen die grondbesitters of regerende klas. Die kleinboer was oorgelewer aan die grille van die regerende klas, wat swaar strawwe gegee het vir selfs die geringste oortredings. 'n Geringe diefstal is met die dood gestraf. Die kleinboere is gedehumaniseer en as 't ware as diere gereken. Hulle kinders is 'n werpsel of broeisel genoem.

\subsubsection{Die stedelike ekonomie}

Die stedelike gemeenskappe het minder as tien persent van ' $\mathrm{n}$ gevorderde agrariese gemeenskap se populasie gehuisves. Die skokkende beeld van die antieke stede is veroorsaak deurdat die geskiedenis geskryf is deur die geletterde minderheid van die regerende klas. Die kenmerkende eienskap van die stede was die groot diversiteit van mense wat daar gebly het. Die inwoners was van een uiterste na die ander uiterste; van die weelderigste regerende klas tot by die bedelaars en sosiaal veragtes wat skaars aan die lewe kon bly. Die stede is nie gekenmerk deur ekonomiese produksie nie, alhoewel handel en vervaardiging daar plaasgevind het. Die stede was die sentrum van welvaartskepping en welvaart-akkumulasie (Josefus, Life; Freyne 2000:54-56). Die stede is geassosieer met politieke en handelsfunksies en veral ook as godsdienstige en kultuursentra (Lenski 1991:201). 


\subsection{Familieverwantskap: 'n Belangrike verandering in die gemeenskap}

Die familieverwantskap ${ }^{5}$ het vir die individu regdeur die agrariese era belangrik gebly.

Die ouers het die huweliksmaats vir hulle kinders gereël. Die primêre belang in 'n huwelik was die ekonomiese en statusimplikasies. Die seksuele, psigologiese en huweliksimplikasies was sekondêr. Die huwelik was primêr 'n ekonomiese transaksie. In die huwelik het die manlike geslag gedomineer en gehoorsaamheid van vrou en kinders was 'n primêre waarde. Die huwelik in 'n agrariese gemeenskap reflekteer 'n outoritêre patroon van lewe. Die familie was dus nie meer die belangrikste integrerende krag in die gemeenskap nie.

Die familie het in die agrariese eeu ook 'n belangrike ekonomiese rol gespeel. Die familie was die basiese eenheid van ekonomiese organisasie. Besighede was meesal familie ondernemings. Die korporatiewe onderneming wat besit is deur 'n groep nieverwante persone het feitlik nie bestaan nie. In die platteland was die kleinboer familie die basiese werkseenheid (vgl Lenski 1991:213).

In gevorderde agrariese gemeenskappe was daar so baie openbare en militêre poste dat die uitgebreide familie nie almal kon vul nie. Familiebande was polities nog steeds belangrik. "The royal office itself was inherited in most societies, as were numerous other political offices. Many of these, civil and military offices alike, were a family's patrimony, handed down like any other family possession from father to son (or,

\footnotetext{
5 Malina (1981:94-121) beskryf die kultureel-antropologiese verstaan van die huwelik of familieverwantskap van die antieke tyd wat radikaal verskil van die 21 ste eeuse verstaan van die huwelik. Sosiale norme verteenwoordig die oughts van 'n groep, die kulturele riglyne waarmee mense, dinge en gebeure verstaan en geëvalueer word. Kinship verwys na patrone van sulke sosiale norme wat menslike verhoudings reguleer wat direk of indirek op die ervaring van geboorte of die geboortesiklus gegrond is. Kinship norme vul basies die biologiese interaksies onder mense met betekenis en waarde. Verwantskap norme simboliseer menslike biologiese interaksies en die resultate of gevolge van sulke interaksies. Die mens word gebore uit die gemeenskap tussen twee mense (sosiale persepsie). Die huwelik verwys na die gemeenskap tussen twee mense insoverre dit verwant is met kinship. Dus is die huwelik 'n onderafdeling van kinship norme. Malina (1981:105-107) onderskei drie huwelikstrategieë in die Bybel, te wete a) Patriargale periode: die versoeningstrategie waar die huwelik gebruik is ter wille van ekonomiese en politieke doelwitte; b) Pre-eksiliese of Israelitiese periode: aggressiewe strategie waar die man die eer van die vrou en dogters beskerm teen die indringing van die elite klasse; en c) Post-eksiliese of Judese periode (tyd van Esra en Nehemia): die defensiewe strategie bepaal dat alle vrouens wat binne die verbond gebore word, behou word en dat huwelike met vreemde vroue verbied word.
} 
sometimes, daughter)" (Lenski 1991:213). Nepotisme is nie in gevorderde agrariese gemeenskappe as 'n oortreding van die wet beskou nie.

\subsection{Stratifikasie met toenemende kompleksiteit}

Die primêre verdeling in die gemeenskap was steeds dié tussen die regerende klas en die groot hoeveelheid kleinboere en andere, waaroor eersgenoemde polities en ekonomies geheers het. Die sosiale stratifikasiesisteem het baie meer kompleks geword. Die kompleksiteit is in die volgende twee areas sigbaar. Eerstens was daar in gevorderde agrariese gemeenskappe baie mense in beroepe wat gewissel het tussen ekstreme. Die mense is of direk in die staat se diens (bv, huisbediendes, bestuurders en soldate) of hulle het indirek die staat gedien (bv, handelaars, vakmanne en skrifgeleerdes). Tweedens is daar in die gevorderde agrariese gemeenskap ' $n$ oorvleueling in die range van verskillende klasse van mense, veral in terme van welvaart en eiendom. Sekere handelaars het byvoorbeeld, meer rykdom as sekere lede van die regerende klas en 'n klein hoeveelheid kleinboere het deur harde werk en geluk meer rykdom as sommige van die verarmde lede van die regerende klas bekom. Die klem val eerder op die gemiddelde van die verskillende klasse as op die individuele lede, want daar is uitsonderings.

Lenski (1991:217) se makro-model oor sosiale stratifikasie in gevorderede agrariese gemeenskappe is deur Duling (1992:101) aangepas en kan soos volg beskryf en voorgestel word: Die heerser was die magtigste, rykste en eerbaarste individu in die gemeenskap: die heerser was letterlik in sy eie klas. Onder die heerser is die regerende klas wat een of twee persent van die bevolking is. Die ander uiterste van hierdie stratifikasie is die geostraseerdes, wat nie deur die gemeenskap benodig word nie. Hulle is gewoonlik die seuns en dogters van die kleinboere wat nie grond geëerf het of ryk getrou het nie, en wat nie werk kan kry nie. Hulle het op 'n vroeë ouderdom gesterf.

Kommersialisering het aanleiding gegee tot opstand en geweld. Die opstande was aanvanklik net plaaslik en het net 'n paar mense betrek. Die kleinboere het in opstand gekom om hulle tradisionele klasverhoudings te herstel of om hulle tradisionele godsdienstige oortuigings te beskerm teen korrupsie. Vakmanne en handelaars het ook in opstand gekom en het gewoonlik die oorhand gekry en self die regerende klas geword. 

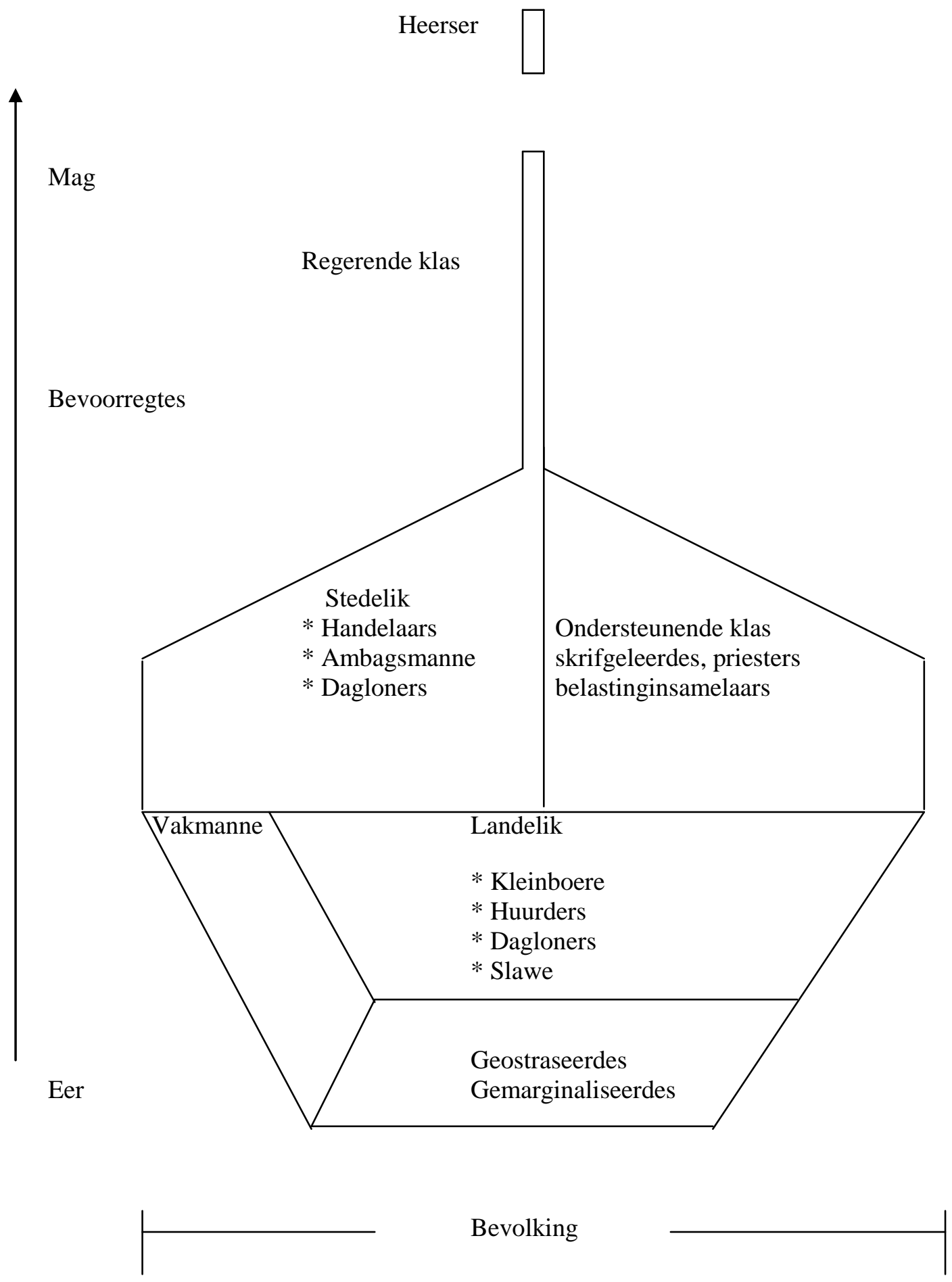


\section{PALESTINA ONDER DIE ROMEINE}

\subsection{Politieke stabiliteit}

Vir 'n eeu en 'n half voordat die Romeine Palestina en Jerusalem (63 vC) verower het, het hulle hulle mag en invloed versprei oor Masedonië, Griekeland en Klein-Asië (moderne Turkye) deur middel van militêre verowering, politieke oorheersing en anneksasie. Binne die Romeinse ryk het ook 'n interne magstryd gewoed (Grant 1982:104; Kee 1997:356). Die stryd vir beheer in Rome gedurende die eerste eeu vC en die konflik onder die magte in die Ooste het 'n reeks krisisse veroorsaak. Die onrus wat veroorsaak is deur die politieke, militêre en ekonomiese oorheersing van die Romeine, wat alle mense in die Ooste beïnvloed het, het 'n groot invloed gehad op die Israeliete in Judea en Galilea van $63 \mathrm{vC}$ regdeur tot met die twee groot oorloë met Rome: die groot oorlog teen Rome in 66-70 nC waarin die tempel verwoes is, en die Bar Kogba-oorlog in 132-135 nC. Na die oorlog is die stad ' $n$ heidense naam gegee en is 'n heidense tempel opgerig waar die Joodse tempel gestaan het (Kee 1997:356). Die oorlog teen Rome in 66 nC het die Joodse regeerders die finale nekslag toegedien.

Pompei het die mag van die Judese staat verminder deur die stede en gebiede te skei van die Joodse regering te skei van die Palestynse areas - Jerusalem, Judea, Idumea en Galilea - wat onder die beheer van die laaste Hasmoniese hoëpriester Hircanus geplaas is. Antipater was die werklike mag agter die troon. Die bestaan van 'n Romeinse kolonie in Jerusalem het die herbou van die muur en opstand verhinder. Dit het die beleid van die Romeine en die simpatieke Griekse stadstate verwesenlik, wat onafhanklikheid gesoek het en 'n einde wou bring aan die sterk Joodse staat. So 'n staat het die vrede in die gebied bedreig en kon lei tot onafhanklike aksie. Kee (1997:358) stel dat die Romeinse oorheersing onder die Idumees, Antipater toegeneem het en die invloed van die tradisionele Joodse regeerders, naamlik die priesters, ryk families en gerespekteerde amptenare en oudstes, vernietig is. Bogenoemde stand van sake is veroorsaak deur die verkrummeling van die Hasmonese heerskappy in Palestina en sosiale wanorde as gevolg van die stryd tussen die Romeinse heersers. Die krisisse en oorloë het gelei tot konsolidasie van die Romeinse Ryk in die Ooste en relatiewe vrede. 


\subsection{Administratiewe sisteem}

Die koms van die Romeine het alles drasties verander. Die gebiede wat vroeër deur die Hasmonieërs verower en ingeneem is, is weggeneem saam met die Judese staat. Hierdie drastiese herorganisasie het baie Judese besitters onteien en 'n sosiale probleem geskep wat tot met die Joodse oorlog bestaan het. Herodus het die tipiese Hellenistiesmonargiese burokratiese apparaat behou. Hy het waarskynlik 'n dubbele administratiewe stelsel gehad - een stelsel vir die plaaslike Joodse bevolking in dorpsgebiede, en 'n ander stelsel vir die meer ge-helleniseerde stedelike gebiede ${ }^{6}$. Die dorp was die basiese administratiewe eenheid gewees. 'n Dorpskrifgeleerde was verantwoordelik vir die monarg se belange. Familiehoofde of oudstes het die dorp verteenwoordig. 'n Aantal dorpe en hulle grond het 'n topargie gevorm (Oakman 1986:44; Kee 1997:357).

Die administratiewe prentjie het min of meer dieselfde gebly na die dood van Herodus tot en met die Joodse oorlog. In die na-70 nC periode het die Romeine Palestina georganiseer langs die grense van die ouer provinsies. Die kenmerk van hierdie saak was om plaaslike gebiede en hulle administrasie aan dorpe te verbind en die bevordering van verstedeliking. Die resultaat van hierdie verstedeliking was dat baie nie-dorpsgebiede in die tweede en derde eeu verander is na stede.

\subsection{Grondbesit onder die Romeine}

Vervolgens gaan ons kyk na die agrariese toestande en die omstandighede van grondbesit in Palestina. Die sosiaal-wetenskaplike eksegese bring op 'n simpatieke wyse teenoor die onderdanige volk, die gevolge van die Romeinse dominansie en eksploitasie na vore. In die Hellenistiese en Romeinse Palestina kon die koning of regeerders die erfreg van die plaaslike kleinboere indring. Hierdie sosiale prerogatief van die magtiges het 'n sekere mate van perke gehad volgens die Grieks-Romeinse reg, veral in die terminologie en prosedures rondom die vervreemding van grond: 'n Onderskeid is by die Grieke en die Romeine gemaak tussen die besit van grond en die gebruik daarvan. Grondbelasting is vasgestel teenoor die gebruik van die grond.

\footnotetext{
${ }^{6}$ Harper (1928:105-168) bespreek die dorpsadministrasie in die provinsie van Sirië, wat 'n breë perspektief op die Romeinse administrasie gee.
} 
Grondbesit sluit sosiale persepsies en vrae oor wettige eienaarskap in en is uitdrukking van sosio-politieke realiteite. Die sosiale geskiedenis van Palestina in die Herodiaanse tydperk hang saam met die geskiedenis van die konsep grond in die Grooten Klein-tradisie ${ }^{7}$ (Fiensy 1991:175-176). Die veranderende konsep wat die Helleniste en die Romeine met hulle saamgebring het, het groot spanning tussen die gewone mense en hulle politieke oorheersers veroorsaak. Die tradisionele konsep wat die Israeliet oor grond gehad het, was dat alle grond aan God behoort en dat die volk dit gehuur het. Die bedoeling was dat elkeen in die opbrengs van die land moes kon deel. Niemand moes permanent van sy grond verwyder word nie, veral nie sy erfgrond nie. Volgens die Rabbynse tradisie ${ }^{8}$ was vervreemding van grond of indringing verbied en is die oordrag van grond as rowery beskou. Die grondonteiening wat plaasgevind het onder die Helleniste en die Romeine het ' $n$ hernude belangstelling in die jubilee laat ontstaan. Die begeerte vir die herinstelling van die jubilee het by die kleinboere en gewone mense geleef (Fiensy 1991:177).

Die vraag is: in watter mate is die grond in die eerste-eeuse Palestina aan die Romeine of hulle kliënte vervreem, en op watter wyse het dit geskied? 'n Algemene proses van vernietiging van die Joodse wettiese siening en die kleinboere wat grond besit het, kan in die Romeinse Palestina veronderstel word, veral onder Romeinse oorheersing voor en na die Joodse oorlog. Oakman (1986:46) stel dat die grondonteieningsproses onder die Romeine gegrond is in die teenoorstaande persepsies oor grondbesit of grondeienarskap. Die onvervreembare erfreg ten opsigte van grondbesit is vervang met privaat eiendomsreg en 'n meer buigbare persepsie van land en kleinboer eksploitasie. Die Grieke, Romeine en Jode het die ou persepsie van grondeienaarskap gehuldig dat die grond die onvervreembare eiendom van die stam is. In die antieke monargiëe het die konings die grond waaroor hulle regeer, as hulle eiendom beskou. Die grond is aan die

\footnotetext{
${ }^{7}$ Die Klein-tradisie is die kultuur van die massa in die onontwikkelde gemeenskappe. Die klein-tradisie is lae kultuur, volkskultuur of populêre tradisie wat oorgelewer word onder die "ongeletterdes" of die "village community". Die Groot-tradisie is die tradisie van die gekultiveerde meerderheid wat opgelei is in skole en tempels, die tradisie van die filosoof, teoloog of letterkundiges. Hierdie tradisie word bewustelik gekultiveer en oorgelewer (Josefus Life 149; Redfield 1956:68-84; kyk Fiensy 1991:2; Freyne 2000:51).

${ }^{8}$ Die saak van die grondonteiening word ook sterk veroordeel in die Rabbynse literatuur, onder andere in Test. Juda 21:7; Test. Dan 5:7; Test. Moses 7:6; 2 Henog 10:5; Jub 9:14. Kyk verder in Singer (1903); Charles (1913), Cronbach (1944:119-156); Fiensy (1991:79, 107).
} 
elite of aristokrasie en kleinboere verhuur. Die magtiges van die antieke tyd het ten spyte van die wette, beheer gevat van wat hulle ookal wou hê.

Die grondbesitbeleid onder die Romeine het verreikende gevolge gehad vir die kleinboer en sy familie, deurdat baie van die bestaansboere hulle plasies verloor en op die grens van hongersnood begin lewe het, hetsy as huurders en of dagloners. Diegene wat wel hulle grond behou het, is erg met belastings aan bande gelê. Vir ander kleinboere het die grond te klein geword en verskeie ander ellendes van die Middelandse See-streek het hulle getref. Soortgelyke toestande het oral in die Grieks-Romeinse wêreld ingetree en veral die bestaansboere diep geraak (Fiensy 1991:178). Groot landgoed het reeds met die draai van die eeu bestaan. Die Hasmonieërs het die landgoed geëerf van die Hellenistiese konings. Herodus het die eiendom van sy politieke vyande gekonfiskeer, bymekaargemaak en versprei. Groot nie-Joodse landbesitters was aan die toeneem. Onder Herodus het die kleinboere in Palestina alreeds onder 'n hiërargie van elite groepe gestaan (Finley 1985:29; Oakman 1986:48; Fiensy 1991:178). Onder die Romeine het die aristokratiese Jode 'n kapitalistiese siening van grond ontwikkel en vir hulle groot en medium groot landgoed opgerig.

\subsection{Besproeiingsboerdery}

Die bevolkingsverspreiding van die Grieks-Romeinse ryk het gesentreer rondom die Middellandse See-gebied. Die Romeine het die Middelandse See, die mare nostrum ons see, genoem. Die meeste van die groot stede was rondom die seegebied gevestig. Die gebiede rondom die Middelandse See het op die periferie gelê en is deur die Romeine soos volg beskou: “... land to be drawn upon for hides, food, metals and slaves, to be raided for booty, to be garrisoned for defence, but to be inhabited by barbarians, not by Greeks or Romans" (Finley 1985:30). Die Mediterreense gebied vorm 'n homogene klimaatsgebied, wat gekenmerk word deur winterreëns en lang somer droogtes; deur ligte grond en droeë boerdery in die grootste gedeeltes. Die gebied is 'n plek met maklike verbouing en baie buitemuurse lewe. Dit bevat van die beste grond; die kusvlaktes en groot binnelandse plato's, wat goeie teelaarde was vir koring, vrugte en groentes, veral druiwe en olyfbome. Die olyfbome was van die primêre verbouings gewees. Dit is 'n 
simbool van gevestigde bestaan. Die Mediterreense gebied het al hoe minder plek vir nomadiese bestaan geword (Grant 1982:105; Finley 1985:31).

In kontras met bogenoemde, staan die Nabye Oosterse ekonomie, wat gebaseer is op droeë boerderymetodes. Die droeë boerderymetodes het nie 'n komplekse sosiale organisasie soos die groot riviervalleigemeenskappe geverg nie. Die besproeiingsboerdery is meer produktief, meer konstant en meer gepas vir 'n groot en digte bevolking. Daarom dat Egipte, die sentrum van besproeiingsboerdery in die Romeinse ryk, 7,5 miljoen inwoners gehad het (Finley 1985:31). Die riviervalleie het in woestyne verander die oomblik wat die sentrale organisasie ophou bestaan het. Daarteenoor, het die antieke droeë boerdery gebiede vinnig herstel na natuurrampe en menslike verwoesting.

\subsection{Belastingstelsel van die Romeine}

Diocletianus het 'n uitmuntende nuwe belastingstelsel in die Romeinse ryk tot stand gebring. Die stelsel was baie kompleks, omdat dit verskillende vorme in verskillende dele van die ryk aangeneem het. Die doel daarmee was om meer doeltreffend te wees. Om die gevraagde belasting op te lewer, moes die belastingstelsel die duidelike, histories bestaande verskille in die landregering erken (Finley 1985:32). Die Romeine het swaar belastings gehef. Na die dood van Herodus het ' $\mathrm{n}$ afvaardiging met Augustus gaan praat oor die swaar belastings en in $17 \mathrm{vC}$ het ' $\mathrm{n}$ afvaardiging met Tiberius gaan praat. Ook Egipte het gekreun onder die swaar las en veral onder Nero is daar ernstig in die Ryk gekla oor belastings. Die belasting het doeane en aksyns ingesluit by verskeie deurgangs-

punte. Een persent belasting is gehef op verkope en vyf persent op die vrylating van slawe en erfbelasting op Romeinse burgers. Ander bronne van belasting was erflatings, boetes, oorlogsbuit, opbrengs vanuit die staatsbeheerde myne en keiserlike landgoed. Direkte belasting (tributum) is op grond en persoonlike besittings gehef buite die grense van Italië. Die reg om belasting in te vorder is aan sekere mense verkoop (publicani), wat maatskappye gevorm het met aandeelhouers in Rome en ander dele van die land. Uitbuiting was aan die orde van die dag (Grant 1982:105). 


\subsection{Handel, industrie en bankwese}

Mynbou het deel gevorm van die ekonomie van die Romeinse Ryk. Die myne het aan die staat behoort en is deur slawe bewerk. Die belangrikste metale wat gemyn is, was goud, silwer, lood, tin, koper en yster. Landbou en vervaardigde goedere is oor land vervoer vanweë die uitstekende padnetwerk van die Romeinse Ryk of vanweë skeepsvaart in die Middellandse see. Die owerheid het 'n koerierdiens gehad vir die amptelike pos, terwyl ander pos deur privaatboodskappers gestuur is.

Die eenheid van die Romeinse Ryk is verstewig deur die eenvormige geldsisteem en munte. As gevolg van die buitelandse en plaaslike konflikte het die waarde van die geldeenheid voortdurend gedevalueer. Tydens hierdie tye het die gewig en silwer inhoud van die munte verlaag. Die geldeenheid was ook 'n propagandamiddel. Die hoof van die keiser is op die muntstuk geplaas en die godsdienstige, militêre en politieke simbole is op die agter kant aangebring. Die simbole het die aandag van die publiek gevestig op belangrike herdenkings. Die Romeinse munte het dus dieselfde funksie gehad as die moderne posseëls (Grant 1982:105). Handel en beleggings is gefasiliteer deur privaatbanke en geldleners.

\subsection{Die Herodiane}

$\mathrm{Na}$ aanleiding van verskillende weergawes van die persoonlikheid van Herodus die Grote, waarsku Botha (1995:997-1019) tereg teen die gevare van dwalinge wat gewoonlik voorkom by die skryf van 'n geskiedenis of weergawes' van 'n kontroversiële figuur soos Herodus die Grote. Eerstens waarsku Botha teen die subjektiewe, interpretatiewe raamwerk van die geskiedskrywer wat gegewens in 'n spesifieke rigting wil indruk (ideologie van die skrywer - GV). Ons selekteer die data wat inpas in ons raamwerk en met tyd word dit tradisie wat meer en meer gekleurd raak, byvoorbeeld dat Herodus volgens Josefus wreed en moorddadig was of dat hy 'n ongelowige heiden was. Sulke negatiewe tekening van 'n invloedryke persoon moet ook verstaan word in terme van die geskiedskrywer, in hierdie geval Josefus, se eie ideologiese bedoelings (kyk McLaren 1998). Die waarskynlikheid van byvoorbeeld, Josefus se uitsprake sal ook met

\footnotetext{
${ }^{9}$ Hanson (1989a, 1989b, 1989c) gee 'n volledige oorsig van die familiale en sosio-ekonomiese agtergrond in die tyd van die Herodiane en Mediterreense wêreld.
} 
behulp van bepaalde kriteria aan falsifikasie onderwerp moet word. Tweedens waarsku Botha dat die antieke bronne net as bewysstukke gebruik word vir die historikus se vooronderstellings. "Die getuienis is daar, die enigste probleem is om die betroubares uit te soek." Derdens waarsku Botha (1995:999) teen die veronderstellings dat ons "in Herodus se hart en verstand kan insien - wat Josefus natuurlik geglo het hy kan doen - en dat dinge gebeur omdat sekere mense besluit om dit te laat gebeur." Laasgenoemde dwaling noem Van Aarde (1985:552) intensiedwaling "wat die oordeelsfout aandui wat die eksegeet maak as hy reken dat hy sonder meer vanuit die wêreld van die teks na die bedoeling in die kop van die outeur as reële persoonlikheid buite die teks kan beweeg." Vierdens wys Botha die historikus tereg op die verkeerde gebruik van terme en konsepte (Botha 1995:999-1000; Pilch 1997:119-125), soos byvoorbeeld Jode waar eintlik Judeërs bedoel word. "Dit is uiters belangrik dat ons ons terme versigtig kies, want sodoende kan ons daarteen waak om slagoffers van die propaganda van ons bronne te word. Maar ons moet ook baie hard werk aan ons verstaansmodelle, anders word hulle (the other) slagoffers van ons propaganda" (Botha 1995:1000). Laastens wys Botha (1995:1006, $1017,1019)$ tereg daarop dat die antieke tekste se sosiale funksie in ag geneem moet word; dat soveel moontlik sosiaal-wetenskaplike makro-en-mikro-modelle gebruik moet word om die verskillende groep(e) se sosio-ekonomiese en kultuur-ideologiese plasing te bepaal. Van Aarde (1994:86) noem dit die sosiale dinamika grondliggend aan die eersteeeuse Judese samelewing.

Hierdie "waarskuwings" sal in ag geneem word wanneer die geskiedenis van Herodus nou weergegee word. Herodus se opkomende politieke mag het saamgeval met die einde van die Hasmonese dinastie, die oorwinning van die Parte deur die Romeine en die opkoms van 'n enkele heerser in Rome. Die heerser se blywende magsposisie was afhanklik van die handhawing van stabiliteit in onder andere Palestina, sodat opeenvolging van magtige Romeinse heersers verseker kan word. Kee (1997:368) beskryf die persoon van Herodus die Grote treffend soos volg:

Herod, who was at times a decadent and arbitrary tyrant, was also an energetic and brave military commander, a ruthless and effective political leader, and an efficient economic and social administrator. He was supported by the Romans because he was able to collect taxes, keep the peace, and provide military 
support at the border of the empire. He remained loyal to the Romans because he had sense enough to know that he could not successfully revolt against Rome. At the same time he was a typical hellenistic despot who killled his opponents.

Herodus het relatiewe veiligheid en onafhanklikheid vir sy volk binne die Romeinse Ryk bewerkstellig. In $31 \mathrm{vC}$ het Herodus verskeie krisisse wat sy posisie bedreig het, oorkom en van daardie tyd af het Herodus veilig geregeer tot met die openbare opstand in sy laaste jare. In dieselfde jaar het 'n aardbewing die ekonomiese basis in meeste van die stede en dorpe vernietig en die belastinginvordering ernstig belemmer. Herodus se posisie in Palestina was totaal afhanklik van die goedheid van keiser Augustus; daarom het Herodus goeie persoonlike bande met die keiser en belangrike hoofamptenare gehandhaaf, soos met Agrippa. Verder is belangrike Griekse stede gebou met tempels, arenas en gimnasiums en baddens ter ere van die keiser. Herodus het soos enige GrieksRomeinse heerser opgetree en is deur die Romeinse Ryk so aanvaar en gerespekteer as deel van hulle regerende klas (Kee 997:370-372).

Herodus was 'n suksesvolle Hellenistiese heerser, maar 'n minder gewilde en bekwame Judese heerser. Herodus het swaar belastinglaste gelê op die volk om die luukse lewenstyl en projekte te ondersteun, as gevolg van sy hoë status in die Romeinse Ryk. 'n Stabiele magsbasis is gehandhaaf deur gewelddadige en konstante onderdrukking van enige vorm van opposisie. Die werk van die ryk en staat is ondersteun deur swaar belasting (meer as 50\%) op die boere te plaas, wat die meerderheid van die bevolking gevorm het. Die ryk was voorspoedig en gekenmerk deur vrede. Die meerderheid van die bevolking was nie entoesiastiese ondersteuners van Herodus nie, maar was ondergeskik aan sy regering uit vrees of ter wille van gemaksug. $\mathrm{Na}$ die dood van Herodus het die opstand onder die laer klasse en die kleinboere in felheid begin toeneem. Die kleinboeropstande was nie georganiseerde revolusie nie, maar die uitwoed van die frustrasie van die volk onder jarelange belastinglas, eksploitasie deur grondonteiening en politieke onderdrukking. Kee $(1997: 376,377)$ stel dat die leiers van die kleinboeropstande hulleself beskou het as konings wat deur God gesalf is en hulle het die ondersteuning van die volk geniet. 
Botha (1995:1017) gee 'n meer gematigde beskrywing van die opstand of teenstand teen Herodus:

\begin{abstract}
Daar was teenstand teen Herodus, maar ons moet daardie teenstand eers verstaan en die groep (of groepe) sosio-ekonomies en kultuur-ideologies kan plaas om die konflikte te interpreteer en reg aan die verskillende partye te laat geskied. Herodus se regeerstyl het ongetwyfeld die retainer en artisan klasse $^{10}$ bevoordeel, ten koste van die tradisionele aristokrasie. Hulle persepsie is nie noodwendig die beste maatstaf waarmee ons moet meet nie. Verder het Herodus die Diaspora Jodedom baie sterk ondersteun en hulle belange in Jerusalem en Palestina bevorder, ... 'n verdere steen des aanstoots vir die tradisionele Judese aristokrasie.
\end{abstract}

Die leiers van die opstande was uit die laer klasse wat deur Herodus swaar belas en onderdruk is. Hulle het aanspraak gemaak op legitieme koninklike gesag, teenoor die illegitieme mag van Herodus, die Romeine en hulle Judese bondgenote. Die opstande is gegrond op die verbondstradisies van die Bybel en het apokaliptiese verwagtings gehad van Goddelike ingryping.

Lenski (1991:217; kyk ook Duling 1992:102) gee 'n grafiese voorstelling van die etic-macro model van die sosiale stratifikasie van die Herodiaanse periode, soos deur Fiensy (1991) bespreek. Die model is belangrik vir die doel van ons studies, omdat ons 'n geheelbeeld kry van die sosiale sisteem. Omdat die model primêr polities en ekonomies is, werp dit meer lig op die moontlikhede van sosiale konflik tussen die aristokratiese elite en die laer sosiale strata.

10 Goodman (1982:417-427) toon 'n noue verband an tussen die kleinboere se opstand en die skuldlas waarin hulle vasgevang was. 


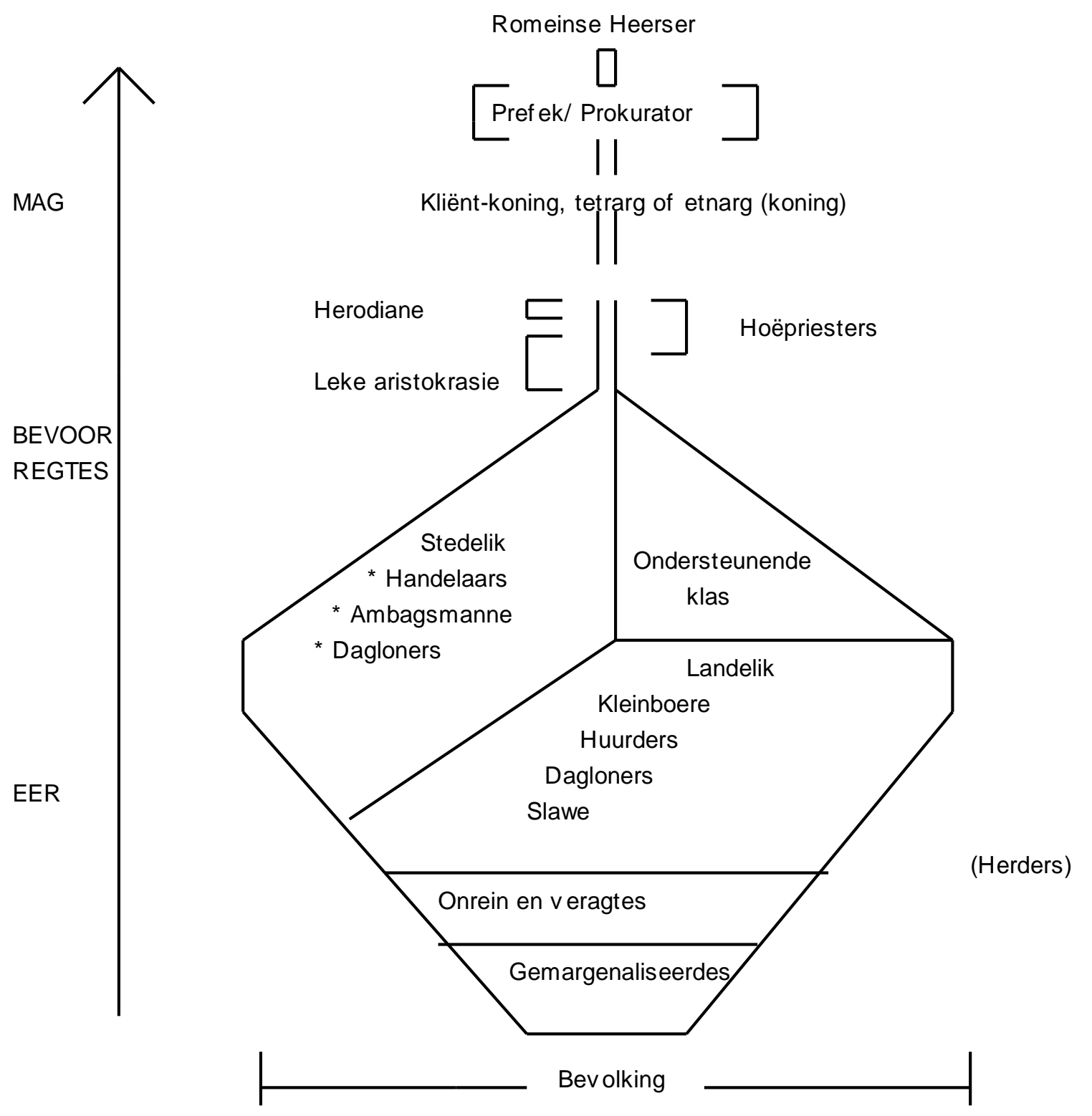

\section{SAMEVATTING}

Polities en ekonomies het die Jode 'n mate van verligting gekry met die oorname deur die Seleukiede. Hulle het verder ook godsdiensvryheid geniet, maar die algemene sosioekonomiese toestande het versleg, sodat 'n resessie ingetree het. Dit is veroorsaak deur droogte en misoeste, maar veral deur die voortdurende oorloë. Nadat die Romeine vir Antiochus III verslaan het, het Antiochus IV oorgeneem. Laasgenoemde het weer die sosio-ekonomiese en politieke onderdrukking van die Jode laat toeneem. Antiochus IV het die Helleniseringsproses laat versnel en die belastinglas het toegeneem. 
Laasgenoemde eksploitasie het aanleiding gegee tot die Makkabese en Joodse kleinboeropstande. Die opkoms van die Hasmoniese ryk het ten doel gehad om politieke, sosio-ekonomiese en veral godsdienstige stabiliteit vir die Jode te bring. Die geskiedenis getuig egter van die teendeel. 'n Groter magstryd het onder die Jode self geheers en groot verdeeldheid tot gevolg gehad. Die grond was steeds 'n bron van stryd en konflik. Die landbou het nie meer die middelpunt van die ekonomie of mag en eer gevorm nie. Die mag en eer het behoort aan die aristokrasie en die monargie, wat die kleinboere en die landvolk geëksploiteer het.

Die eerste-eeuse Mediterreense wêreld onder Romeinse heerskappy word beskou as 'n gevorderde agrariese samelewing. Die tydperk is gekenmerk met hoë tegnologiese ontwikkeling en ontdekkings, waarvan yster baie belangrik was. Die ekonomie staan op die stadium bekend as die bestaansekonomie. Die grondbesitters het die ekonomie beheer. As gevolg van te veel skuld het die kleinboere hulle grond verloor, wat in die hande van die afwesige grondeienaars beland het. Die afwesige grondeienaars het in die stede gewoon. Die stedelike ekonomie waarin die mag van die regeerders gesentreer het, het geparasiteer op die landelike ekonomie. Die landbousurplus is deur die elite ingepalm of deur belastings uitgeput. Die landelike ekonomie het op verskeie terreine in die stedelike ekonomie se behoefte voorsien. Die regerende elite het politieke stabiliteit probeer handhaaf, omdat die hele bestaansekonomie van die landbou afhanklik was. Die regerende elite en die stede het die landelike gebiede en die kleinboere geëksploiteer. Die stede was die middelpunt van die samelewing, sosio-ekonomies, polities en godsdienstig.

Die oorsig van die gevorderde agrariese samelewing (kyk afdeling 4) bevestig dat die familiale instelling die oorheersende instelling was (Malina 1981; Elliott 1991; Van Eck 1995). Die familie het 'n belangrike ekonomiese rol vervul en is die kleinste sosioekonomiese en godsdienstige bousteen. Die huwelik was primêr 'n patriargale sisteem waar die man gedomineer het. Die stratifikasie het in kompleksiteit toegeneem. Die regerende klas het al ryker geword en meer grond beheer, terwyl die kleinboere en landvolk al armer geword het (vgl diagram). Die gevolgtrekking is dat die evolusie vanaf hortikultureel na simplistiese agrariese samelewing kulmineer in die gevorderde agrariese samelewing. Kenmerkend van laasgenoemde samelewing is die stryd (kenmerkend van 'n agoniese/wedywerende samelewing - vgl Malina 1981:94) om grondbesit, die stryd 
tussen die stad en platteland, die sosiale stratifikasie en die sentraliteit van die familiale instelling. Bogenoemde elemente is die antesedente van die Bybelse jubilee.

Die Romeinse oorheersing van Israel het ook gepaard gegaan met magstryd en opstande. Die regerende klas of elite het die kleinboere en armes uitgebuit en onderdruk. Die grondbesitters is eenvouding onteien en die afwesige grondeienaars het in getalle toegeneem. Die tradisionele stryd tussen stad en platteland is voortgesit. Die Romeine het ' $n$ sterk teenwoordigheid in Jerusalem gehandhaaf om sodoende die Judese onafhanklikheidstrewe teen te werk. Die persepsie oor grondbesit en die jubilee is onder die Romeinse heerskappy tot op die spits gedryf. Die Romeinse regeerders en die Judese aristokrate het die kleinboere deur middel van belastings en heffings van hulle grond vervreem. Die ontstaan van groot landgoed in die hande van die elite het begin toeneem. Die eksploitasie en grondonteiening van die kleinboere het die begeerte van die herinstelling van die jubilee laat toeneem. Water is ' $\mathrm{n}$ belangrike bron van voortbestaan; daarom het groot stede rondom die Middellandse See ontstaan. Die besproeiingsboerdery was meer standhoudend as die rivier-valleie.

Die Romeine het 'n doeltreffende belastingstelsel regdeur die Romeinse Ryk gehad. Die belasting invordering was ook doeltreffend. Die bevolking het swaar belastings betaal en niks was vrygestel nie. Geld was wyd in omloop en het die eenheid van die Romeinse Ryk bevorder. Munte is ook as propaganda gebruik vir die Romeinse oorheersers, met 'n afdruk van hulle hoofde daarop.

Onder die Herodiane het sowel die eksploitasie van die kleinboere as die weerstand daarteen in felheid toegeneem. Die weerstand het 'n hoogtepunt bereik by die kleinboeropstande. Die verbondstradisies en herinstelling van die jubilee het ' $\mathrm{n}$ belangrike rol gespeel in die kleinboeropstande. Botha (1995) gee belangrike kriteria wat gebruik moet word in die vorming van 'n persepsie van die antieke situasie, asook in die gebruik van die antieke bronne in die beskrywing van die geskiedenis.

\section{Literatuurverwysings}

Botha, P J J 1995. Herodus - die Grote? HTS 51(4), 996-1028

Charles, R H 1913. Pseudepigrapha. Oxford: Clarendon.

Cronbach, A 1944. The social ideals of the Apocrypha and the Pseudepigrapha. HUCA $18,119-156$. 
Duling, D C 1992. Matthew's plurisignificant "Son of David" in social-science perspective: Kinship, kingship, magic and miracle. BTB 22, 99-116.

Elliott, J H 1991. Temple versus household in Luke-Acts: A contrast in social institutions, in Neyrey, J H (ed), The social world of Luke-Acts: Models for interpretation, 211-240. Minneapolis: Fortress.

Fiensy, D A 1991. The social history of Palestine in the Herodian period. Lewiston, NY: Edwin Mellen. (Studies in the Bible and early Christianity 20.)

Finley, M I 1985. The ancient economy. New York: Penguin Books.

Freyne, S 2000. Galilee and gospel: Collected essays. Tübingen: Mohr Siebeck.

Goodman, M 1982. The first Jewish revolt and the problem of debt. Journal of Jewish Studies 30, 417-427.

Grant, R M 1982. s v Roman Empire. IDB.

Hanson, K C 1989a. The Herodians and Mediterranean kinship, Part I: Genealogy and descent. BTB 19, 75-84.

Hanson, K C 1989b. The Herodians and Mediterranean kinship, Part II: Marriage and divorce. ВTB 19, 142-151.

Hanson, K C 1989c. The Herodians and Mediterranean kinship, Part III: Economics. BTB 19, 10-21.

Harper, G M 1928. Village administration in the Roman province of Syria. Yale Classical Studies 1, 105-168.

Hengel, M 1973. Judaïsm and Hellenism: Studies in their encounter in Palestine during the early Hellenistic period. Tübingen: Mohr.

Josephus, F 1926-1956. Works, tr by Thackeray, H J et al. 10 vols. London: Harvard University Press.

Kee, H C et al 1997. The Cambridge companion to the Bible. Cambridge: Cambridge University Press.

Lenski, G, Lenski, J \& Nolan P (1970) 1991. Human societies: An introduction to macrosociology. Sixth Edition. New York: McGraw-Hill.

Louw, J P 1983. Hellenisme. Ongepubliseerde klasaantekeninge, Universiteit van Pretoria.

Malina, B J 1981. The New Testament world: Insights from cultural anthropology. Atlanta: John Knox. 
McLaren, J S 1998. Turbulent times? Josephus and scholarship on Judaea in the first century C E. (Journal for the study of the Pseudepigrapha - Supplement Series 29). Sheffield: Sheffield Academic Press.

Oakman, D 1986. Jesus and the economic questions of his day. Lewiston: Edwin Mellon. (SBEC 8.)

Pilch, J J 1997. Are there Jews and Christians in the Bible? HTS Theological Studies $51(1 \& 2), 119-125$.

Redfield, R 1956. Peasant society and culture. Chicago: University of Chicago Press.

Singer, I 1903 (ed). Jewish Encyclopedia. New York: Funk \& Wagnals.

Van Aarde, A G 1985. Skrifgebruik: Hermeneutiese riglyne. HTS 41(4), 547-578.

Van Eck, E 1995. Galilee and Jerusalem in Mark's story of Jesus: A narratological and social scientific reading. Pretoria: Promedia Printers. (HTS Suppl 7).

Volschenk, G J 2002. Die ontwikkeling vanaf 'n horti-kulturele na 'n simplistiese agrariese ekonomie in die leefwêreld van die Bybel. HTS 58(3), 1089-1112. 